\title{
Evaluation of milk yield losses associated with Salmonella antibodies in bulk tank milk in bovine dairy herds
}

\author{
T. D. Nielsen, ${ }^{*}{ }^{1}$ L. E. Green,$\dagger$ A. B. Kudahl, $\neq$ S. Østergaard, $\neq$ and L. R. Nielsen* \\ *Department of Large Animal Sciences, Faculty of Health and Medical Sciences, University of Copenhagen, Grønnegårdsvej 8, \\ DK-1870 Frederiksberg C, Denmark \\ †School of Life Sciences, University of Warwick, Coventry CV4 7AL, United Kingdom \\ ‡Faculty of Agricultural Sciences, Institute of Animal Health and Bioscience, University of Aarhus, Denmark
}

\begin{abstract}
The effect of Salmonella on milk production is not well established in cattle. The objective of this study was to investigate whether introduction of Salmonella into dairy cattle herds was associated with reduced milk yield and determine the duration of any such effect. Longitudinal data from 2005 through 2009 were used, with data from 12 mo before until 18 mo after the estimated date of infection. Twenty-eight case herds were selected based on an increase in the level of Salmonella-specific antibodies in bulk-tank milk from $<10$ corrected optical density percentage (ODC\%) to $\geq 70$ ODC $\%$ between 2 consecutive three-monthly measurements in the Danish Salmonella surveillance program. All selected case herds were conventional Danish Holstein herds. Control herds $(\mathrm{n}=40)$ were selected randomly from Danish Holstein herds with Salmonella antibody levels consistently $<10$ ODC\%. A date of herd infection was randomly allocated to the control herds. Hierarchical mixed effect models with the outcome test-day yield of energy-corrected milk $(\mathrm{ECM}) /$ cow were used to investigate daily milk yield before and after the estimated herd infection date for cows in parities 1,2 , and $3+$. Control herds were used to evaluate whether the effects in the case herds could be reproduced in herds without Salmonella infection. Herd size, days in milk, somatic cell count, season, and year were included in the models. Yield in first-parity cows was reduced by a mean of $1.4 \mathrm{~kg}$ (95\% confidence interval: 0.5 to 2.3 ) of $\mathrm{ECM} /$ cow per day from 7 to 15 mo after the estimated herd infection date, compared with that of first-parity cows in the same herds in the 12 mo before the estimated herd infection date. Yield for parity $3+$ cows was reduced by a mean of $3.0 \mathrm{~kg}$ (95\% confidence interval: 1.3 to 4.8) of ECM/cow per day from 7 to 15 mo after herd infection compared
\end{abstract}

Received March 3, 2011.

Accepted April 16, 2012.

${ }^{1}$ Corresponding author: tdni@life.ku.dk with that of parity $3+$ cows in the 12 mo before the estimated herd infection. We observed minor differences in yield in second-parity cows before and after herd infection and observed no difference between cows in control herds before and after the simulated infection date. Milk yield decreased significantly in affected herds and the reduction was detectable several months after the increase in bulk tank milk Salmonella antibodies. It took more than $1 \mathrm{yr}$ for milk yield to return to preinfection levels.

Key words: Salmonella, bulk-tank milk antibody, dairy cattle, milk yield

\section{INTRODUCTION}

Salmonella is a common cause of food poisoning, with more than 130,000 confirmed cases in the European Union in 2008 (European Food Safety Authority, 2010). Although chicken and pork are the major animal sources of Salmonella, milk and beef cannot be excluded as a cause of human salmonellosis. In Denmark, Salmonella Dublin is the most frequently isolated serotype from beef with more than $60 \%$ of isolates from domestic beef (National Food Institute, 2010). Salmonella Dublin was the fourth most common serotype isolated from diseased humans in Denmark in 2009 (National Food Institute, 2010), and this serotype has been reported to lead to higher case mortality rates in humans than other serotypes (Helms et al., 2003). Salmonella Dublin is also the most frequently isolated serotype of Salmonella in cattle with clinical salmonellosis in Denmark (National Food Institute, 2009). It is host-adapted to cattle and can create carrier animals and cause endemic infection in cattle herds (House et al., 1993; Veling, 2004). Since 2002, a surveillance program has monitored cattle herds in Denmark, where all dairy herds are tested at 3-mo intervals. In this program, an inhouse ELISA test (Eurofins Denmark, Glostrup, Denmark) is used to detect antibodies against LPS antigens from Salmonella Dublin in bulk-tank milk (BTM). The ELISA test might cross-react with other Salmonella 
serotypes, mainly Salmonella Typhimurium, in Danish cattle herds. Herds are classified either "most likely free of Salmonella Dublin" (level 1) or "most likely infected with Salmonella Dublin" (level 2; Warnick et al., 2006; National Food Institute, 2009). A shift from test-negative (level 1) to test-positive (level 2) is indicative of Salmonella infection spreading among lactating cows (Nielsen and Ersbøll, 2005).

Decreased milk yield has been reported in cows from herds with Salmonella infection. One herd investigated by Anderson et al. (2001) experienced a Salmonella Agona outbreak with decreased milk yield. Hermesch et al. (2008) reported that cows vaccinated against Salmonella Newport during their dry period, produced on average $1.2 \mathrm{~kg} / \mathrm{d}$ more milk for the first $90 \mathrm{~d}$ in the subsequent lactation than nonvaccinated cows in one dairy herd, but that the expected 305-d yield did not differ significantly. That herd had no clinical signs, although Salmonella Newport was isolated from fecal samples of cows. A Salmonella Dublin outbreak in a 100-cow dairy herd in England caused a severe decrease in milk yield (Bazeley, 2006): a milk-loss of 19,430 L over approximately 2 mo was estimated. John (1946) reported a severe decrease in milk yield and that some cows even stopped producing altogether when infected with Salmonella Dublin. In addition, according to Vandegraaff and Malmo (1977), a severe decrease in milk production was seen in cows clinically affected by Salmonella Dublin, but most cows returned to normal production within $10 \mathrm{~d}$ of beginning treatment. In contrast to this, other authors have reported cows shedding Salmonella without any signs and overall milk yield similar to that of herds without reports of Salmonella infection (Gay and Hunsaker, 1993; Huston et al., 2002). However, overall yield varies from herd to herd, so it might be difficult to show effects of Salmonella on milk yield by comparing herds. House et al. (2001) found no effect on 305-d yield in a herd where they compared yield in unvaccinated cows to that in cows vaccinated with an autogenous Salmonella Montevideo vaccine or in cows vaccinated with a modified live Salmonella Cholerasuis vaccine. However, in testing the herd for Salmonella before the study, 9 serotypes of Salmonella were isolated from fecal cultures of cows, so it is not known which, if any, of the 9 serotypes were affecting milk yield.

Compared with our study, very few studies have included a larger number of herds and, to our knowledge, none have quantified the within-herd changes in milk yield for an extended period before and after herd infection with Salmonella. Furthermore, no studies have estimated how long it takes before the herd milk yield returns to preinfection levels. This is important information for the farmer and the industry to quantify production and economic losses from reduced milk yield.
Such information will be useful for the Danish Cattle Federation (Aarhus, Denmark) to motivate farmers to prevent and control Salmonella. The estimates of milk yield effects are also useful for further research such as simulation modeling of long-term effects of Salmonella infection in dairy herds. The objective of the current study was to investigate long-term changes in milk yield in Danish dairy herds that experienced large increases in BTM antibodies directed against Salmonella Dublin between 2005 and 2009. A large increase in the concentration of BTM antibodies was assumed to be a sign of spread of Salmonella in the herd.

\section{MATERIALS AND METHODS}

\section{Salmonella Status of Herds}

All Danish dairy herds are tested quarterly in the Danish Salmonella surveillance program and a herd is classified as level 2 if the average of the last 4 BTM ELISA test results is $\geq 25$ corrected optical density percentage (ODC\%) compared with a negative control test (Nielsen et al., 2007b). The positive predictive value of the herd-testing scheme has been estimated to be between 0.47 and 0.88 , depending on the prevalence of infected herds, and the negative predictive value has been estimated to be above 0.96 when between-herd prevalence is $<30 \%$ (Warnick et al., 2006). Thus, level 2 herds are not always infected, whereas level 1 herds are most likely uninfected. We decided, therefore, to improve the positive predictive value for detection of newly infected herds in this study by restricting the case herd group to herds with large increases in BTM antibody levels as described in the Selection of Herds section below.

\section{Selection of Herds}

The study was based on registry data from the Danish Cattle Database (Knowledge Centre for Agriculture, Cattle, Århus, Denmark) from January 2005 to December 2009. Selection of herds was based on their BTM Salmonella ODC\% measurements from the Danish surveillance program. A herd was included as a case herd if (1) it had an antibody response $<10$ ODC\% in at least 3 samples over a minimum of $1 \mathrm{yr}$ followed by an increase to $\geq 70$ ODC $\%$ and (2) the test following the initial high test was $\geq 25$ ODC\% (to exclude potential false positives). Out of approximately 3,300 dairy herds, 44 herds fulfilled these criteria. Two additional herds had an antibody response $<25$ ODC $\%$ in the test following the initial test but an antibody response $\geq 25$ ODC\% in subsequent tests. This indicated that they were infected with Salmonella and they were included 
as case herds. The 46 herds were stratified on main breed, farming type (conventional or organic), and herd size and were analyzed descriptively. The largest group consisted of conventional Danish Holstein dairy herds, and 28 herds with a minimum of 40 cows in the study period were selected as case herds. The following herds were excluded from the model: 5 herds with no milk yield recordings around the estimated time of infection, 4 herds not consisting of Danish Holsteins (1 Jersey, 2 Danish Reds, and 1 crossbreed), 1 herd consisting of $<40$ cows in the study period, and 8 organic herds. Forty control herds were randomly selected from conventional Danish Holstein herds with $>40$ cows in the study period and antibody response $<10$ ODC\% throughout the study period.

\section{Test-Day ECM Yield}

The outcome variable was test-day ECM yield $(\mathrm{kg})$. It was measured as part of the milk recording scheme, a voluntary system in which information of individual cow milk yield is routinely recorded up to 11 times per year. Milk yield (kg), SCC, and fat and protein percentages are recorded in this program and reported to the farmer. Test-day ECM is calculated as follows:

$$
\begin{gathered}
\text { Test-day } \mathrm{ECM}=[\text { milk in } \mathrm{kg} \times(383 \times \% \text { fat } \\
+242 \times \% \text { protein }+780.8)] / 3,140
\end{gathered}
$$

This is a common way to calculate test-day ECM in Denmark and is a slight modification of the calculation proposed by Sjaunja et al. (1990).

From the test-day ECM recordings, a basic lactation curve was modeled as a function of DIM truncated at $305 \mathrm{~d}$ and the Wilmink function: $\exp (\mathrm{ECM})^{(-0.05 \times \mathrm{DIM})}$ (Wilmink, 1987). The Wilmink function is an exponential function that models the natural shape of lactation curves by adjusting for DIM with increasing milk yield until around d 60 and then decreasing milk yield throughout the rest of the lactation.

\section{Time Periods}

An estimated infection date of $61 \mathrm{~d}$ before the registered increase in BTM Salmonella ODC\% was set for each case herd. This was chosen to allow for spread of Salmonella from the animal initially infected to other animals in the herd and it accounted for the fact that it takes 2 wk from infection to seroconversion (Robertsson, 1984). Furthermore, we were unlikely to identify the first day of high ODC\%, because herds were only tested every 3 mo. A variable for 3 -mo time periods $(\mathbf{T})$ was included in the model to represent time before and after infection, where $T_{0}$ was 1 to 3 mo after the estimated infection date, $\mathrm{T}_{1}$ was 4 to 6 mo after infection, $\mathrm{T}_{-1}$ was 1 to 3 mo before estimated infection date and so on; T-values ranged from $\mathrm{T}_{-4}$ to $\mathrm{T}_{5}$. A simulated infection date, weighted by year and month of infection in the case herds, was set for each control herd to ensure that $\mathrm{T}_{\mathrm{i}}$ were comparable for control and case herds. Three control herds had estimated infection dates late in 2008 so $T_{5}$ had no test-day ECM observations.

\section{Season}

Test-day ECM displayed a marked seasonality with the highest yield in spring and the lowest in fall. A sine curve was created for each parity, with amplitude depending on the difference between year-quarter with highest and lowest yields for the control herds, where year-quarters were January to March, April to June, July to September, and October to December. This difference in yield between spring and fall was 1.5, 1.5, and $1.9 \mathrm{~kg}$ of test-day ECM for parities 1, 2, and 3+, respectively. The sine curve was given by:

$$
\begin{gathered}
\text { Sine }=\text { difference in milk yield } \times \operatorname{sine}(2 \times \pi \\
\times \text { year-quarter } / 4) .
\end{gathered}
$$

The sine value was thus constant throughout each quarter of a year and had only 4 values for each parity. Model fit for parity $3+$ cows was better when seasonality was included as season (March to May, June to August, September to November, and December to February) rather than the sine curve. Hence, season was included in the model for this parity instead of year-quarter.

\section{Other Confounding Variables}

Other variables known to affect milk yield were included in the study: year, log SCC, parity $(1,2$, and $3+)$. All data were extracted from the milk recording scheme. Herd size was calculated as the mean number of cows per test date and was included at the herd level. One control herd increased from approximately 80 to 200 cows, and data from this herd were excluded after herd size increased (meaning that data from part of $\mathrm{T}_{4}$ and all of $\mathrm{T}_{5}$ were deleted).

\section{Data Analysis}

Descriptive statistics were performed in SAS (version 9.2, SAS Institute, Cary, NC). Effects on test-day ECM were analyzed using a multilevel model in MLwiN 2.21 (Rasbash et al., 2009). The outcome variable had a 
Table 1. Attributes of 40 control study herds and 28 case study herds with large, sudden increases in bulk tank milk Salmonella antibody levels indicative of recent herd infection

\begin{tabular}{|c|c|c|c|c|c|c|c|c|c|c|}
\hline \multirow[b]{2}{*}{ Item } & \multicolumn{5}{|c|}{ Case herds $(n=28)$} & \multicolumn{5}{|c|}{ Control herds $(\mathrm{n}=40)$} \\
\hline & Mean & Median & Q1-Q31 & Range & Total & Mean & Median & Q1-Q3 & Range & Total \\
\hline Observations/cow & 10.1 & 9 & $5-15$ & $1-26$ & 54,911 & 10.0 & 9 & $5-15$ & $1-25$ & 64,903 \\
\hline Cows & 194 & 203 & $107-266$ & $62-433$ & 5,436 & 163 & 161 & $99-221$ & $44-336$ & 6,523 \\
\hline Cows/test date & 79 & 79 & $46-106$ & $21-236$ & 693 & 68 & 67 & $47-88$ & $10-155$ & 956 \\
\hline
\end{tabular}

${ }^{1} \mathrm{Q} 1=25 \%$ quartile; Q3 $=75 \%$ quartile.

normal distribution. The hierarchical structure of the data was test-day ECM within cow within herd, and we used an iterative generalized least squares means procedure for estimations. There were 1.6 parities per cow on average, so each parity was modeled separately. All relevant 2-way interactions were included in the model by forward selection, if they were significant at $5 \%$ and if they improved model fit. The final model for parity 1 and 2 was as follows:

$$
\begin{gathered}
\text { Test-day } \mathrm{ECM}_{\mathrm{ijk}}=\beta 0_{i j k}+\operatorname{DIM}\left(X_{i j k}\right) \\
+\exp (\mathrm{ECM})^{(-0.05 \times \mathrm{DIM})}\left(X_{i j k}\right)+\log (\operatorname{SCC})\left(X_{i j k}\right) \\
+\operatorname{Sine}\left(X_{i j k}\right)+\text { Year }+\mathrm{T}+\mathrm{T} \times \operatorname{DIM}\left(X_{i j k}\right) \\
+\mathrm{T} \times \operatorname{Sine}\left(X_{i j k}\right)+\mathrm{T} \times \text { Year }+\operatorname{Year} \times \operatorname{Sine}\left(X_{i j k}\right) \\
+v_{k}+u_{j k}+e_{i} .
\end{gathered}
$$

For parity $3+$ the final model was

$$
\begin{gathered}
\text { Test-day } \mathrm{ECM}_{\mathrm{ijk}}=\beta 0_{i j k}+\operatorname{DIM}\left(X_{i j k}\right) \\
+\exp (\mathrm{ECM})^{(-0.05 \times \mathrm{DIM})}\left(X_{i j k}\right)+\log (\mathrm{SCC})\left(X_{i j k}\right) \\
+ \text { Season }+ \text { Year }+\mathrm{T}+\mathrm{T} \times \operatorname{DIM}\left(X_{i j k}\right) \\
+\mathrm{T} \times \text { Season }+\mathrm{T} \times \text { Year }+v_{k}+u_{j k}+e_{i} .
\end{gathered}
$$

For all models, test-day $\mathrm{ECM}_{i j k}$ is milk yield on test day $i$ for cow $j$ in herd $k, \beta 0$ is the intercept on test day $i$ for cow $j$ in herd $k, \mathrm{X}_{i j k}$ are the fixed effects varying by cow observation, $v_{k}$ random effect of herd, $u_{j k}$ random effect of cow, and $e_{i}$ residual error at the outcome level for test-day ECM.

Test-day ECM was modeled from 12 mo before $\left(\mathrm{T}_{-4}\right)$ to 18 mo after $\left(T_{5}\right)$ the estimated infection date for the herd. Control and case herds were modeled separately. The final models for control herds were applied to the respective parity case herd data to assess associations between test-day ECM and Salmonella. Year 2005 was used as baseline in the model, and data were centered on mean of $\log \mathrm{SCC}(4)$, corresponding to an SCC of approximately 55,000 cells/mL. Fall was used as baseline for parity $3+$. Standard residuals for each level in the model and predicted versus observed test-day ECM were plotted to assess model fit.

\section{RESULTS}

The 68 herds in the data set included 119,814 testday ECM observations from 11,959 cows, with 5,436 cows in the case herds and 6,523 cows in the control herds. Comparison of case and control herds is presented in Table 1. Each cow contributed between 1 and 26 observations (mean $=10)$. The case herds were, on average, larger than the control herds, with more cow observations and cows per herd as well as more cows per test date. Descriptions of $\operatorname{logSCC}$ and milk yield for the different parities are given in Table 2. Case herds had a lower proportion of parity $3+$ observations than did control herds. The distribution of observations in

Table 2. Descriptive statistics for test-day ECM yield and log to SCC (LogSCC) for 40 control herds and 28 case herds with large, sudden increases in bulk tank milk Salmonella antibody levels indicative of recent herd infection ${ }^{1}$



${ }^{1} \mathrm{n}$ represents number of test-day ECM samples. 
$T_{\mathrm{i}}$ can be seen in Table 3. Generally, $\mathrm{T}_{5}$ included fewer observations because some herds had an estimated time of infection late in 2008.

Results from the model for case herds for parities 1 and 2 are given in Table 4 and for parity $3+$ in Table 5. Interactions between $\mathrm{T}$ and DIM, year, and season or sine were significant in all parities. An interaction between sine and year for parity 1 and 2 was also significant (data shown in Appendix Tables A1 and A2). Parity 1 cows had reduced yield in $T_{3}$ and $T_{4}$ (10 to 15 mo after the estimated herd infection date), as well as borderline significantly reduced yield in $\mathrm{T}_{2}$ ( 7 to 9 mo after the estimated herd infection date). Parity $3+$ cows had the largest reduction in yield for the period $\mathrm{T}_{2}$ to $\mathrm{T}_{4}$. The mean daily milk loss in the period 7 to 15 mo after the estimated herd infection was $1.4 \mathrm{~kg}$ of $\mathrm{ECM} /$ cow per day ( $95 \%$ CI: 0.5 to $2.3 \mathrm{~kg}$ ) for parity 1 cows and $3.0 \mathrm{~kg}$ of ECM/cow per day (95\% CI: 1.3 to $4.8 \mathrm{~kg}$ ) for parity $3+$ cows (Figure 1 ). Parity 2 cows had decreased yield in $\mathrm{T}_{4}$. For a herd with 100 cow-years and 36,32 , and $32 \%$ of the cows in parity 1, 2 and $3+$, respectively, the mean loss in milk production would be more than 40,000 kg of ECM (95\% CI: 8,000-153,000) in the first year after infection.

Milk yield from cows in control herds was lower in $\mathrm{T}_{-2}$ for parity $2($ mean $=-2.7 \mathrm{~kg}$ of $\mathrm{ECM} /$ cow per day, $95 \%$ CI: -3.7 to $-0.8 \mathrm{~kg})$ and borderline significantly reduced in $\mathrm{T}_{-1}$ for parity 1 (mean $=-1.0 \mathrm{~kg}$ of ECM/ cow per day, $95 \%$ CI: -2.0 to $0.1 \mathrm{~kg}$; Figure 1).

Average herd size was not significant in control or case herds and did not act as a confounder on other variables so it was omitted from the models. Likewise, the interaction between $\mathrm{T}$ and the Wilmink function was tested in the models, but did not change the model estimates or significance of other variables and was therefore excluded. Plots of standard residuals and predicted versus observed test-day ECM showed acceptable model fit for all parities (data not shown). Only minor correlations were observed between $\mathrm{T}$ and calendar month, although the estimated infection date was strongly seasonal (data not shown).

\section{DISCUSSION}

In our study, we observed a significant reduction in milk yield 7 to 15 mo after the estimated herd infection date $\left(T_{2}\right.$ to $\left.T_{4}\right)$ for cows in parities 1 and $3+$. These findings are similar to those reported by others where newly infected cows or herds had a decrease in milk yield (Vandegraaff and Malmo, 1977; Anderson et al., 2001; Bazeley, 2006) but we have quantified the milk loss. Other authors (McClure et al., 1989; Huston et al., 2002; Van Kessel et al., 2007) reported no association between Salmonella infection and milk yield; however, 
Table 4. Multilevel analysis for fixed effects on test-day ECM for parity 1 and 2 for 28 Danish Holstein herds with large, sudden increases in bulk tank milk Salmonella antibody levels indicative of recent herd infection

\begin{tabular}{|c|c|c|c|c|c|c|c|c|}
\hline Variable & \multicolumn{4}{|c|}{ Parity 1} & \multicolumn{4}{|c|}{ Parity 2} \\
\hline DIM & -0.02 & 0.00 & -0.02 & -0.02 & -0.05 & 0.00 & -0.05 & -0.04 \\
\hline $\operatorname{Exp}(\mathrm{ECM})^{(-0.05 \times \mathrm{DIM})}$ & -5.77 & 0.20 & -6.16 & -5.37 & -5.03 & 0.29 & -5.59 & -4.47 \\
\hline Log SCC & -0.25 & 0.03 & -0.31 & -0.18 & -0.51 & 0.04 & -0.59 & -0.43 \\
\hline \multicolumn{9}{|l|}{ Year } \\
\hline 2007 & 3.31 & 0.90 & 1.54 & 5.08 & 3.05 & 2.17 & -1.20 & 7.30 \\
\hline 2008 & 3.65 & 0.95 & 1.79 & 5.51 & 3.30 & 2.21 & -1.03 & 7.63 \\
\hline 2009 & 5.19 & 1.06 & 3.11 & 7.26 & 5.28 & 2.31 & 0.76 & 9.81 \\
\hline Sine season & -0.29 & 0.27 & -0.82 & 0.23 & -0.44 & 0.39 & -1.21 & 0.33 \\
\hline \multicolumn{9}{|l|}{ Standardized test-day } \\
\hline \multicolumn{9}{|l|}{ ECM/time period ${ }^{2}$} \\
\hline$-4(-12$ to -10$)$ & 1.29 & 0.92 & -0.51 & 3.09 & 2.84 & 2.20 & -1.47 & 7.14 \\
\hline $2(7$ to 9$)$ & -0.82 & 0.45 & -1.71 & 0.06 & 1.24 & 0.67 & -0.07 & 2.55 \\
\hline $3(10$ to 12$)$ & -1.30 & 0.47 & -2.23 & -0.37 & -0.94 & 0.70 & -2.30 & 0.43 \\
\hline $4(13$ to 15$)$ & -1.99 & 0.48 & -2.93 & -1.04 & -1.73 & 0.70 & -3.10 & -0.37 \\
\hline $5(16$ to 18$)$ & 0.36 & 0.45 & -0.52 & 1.25 & 0.48 & 0.65 & -0.79 & 1.75 \\
\hline \multicolumn{9}{|l|}{ Random effects } \\
\hline Herd-level variance & 8.95 & 2.45 & & & 11.96 & 3.31 & & \\
\hline Cow-level variance & 15.53 & 0.43 & & & 24.93 & 0.80 & & \\
\hline Test-day ECM level variance & 11.30 & 0.12 & & & 18.34 & 0.22 & & \\
\hline
\end{tabular}

${ }^{1} \mathrm{LCL}$ and UCL $=$ lower and upper confidence limits.

${ }^{2}$ Time period in months relative to estimated herd infection is shown in parentheses.

in those studies, the time of introduction of Salmonella was not known, so the authors merely reported associations between seropositivity and milk yield.

The greatest overall reduction in yield was seen in parity $3+$ cows. Other authors report greater reductions in milk yield in higher parity cows with mastitis (Bennedsgaard et al., 2003) and greater susceptibility to mastitis (Breen et al., 2009), and a similar pattern with lameness (Amory et al., 2008; Sanders et al., 2009). It is therefore possible that milk yield of parity $3+$ cows was more affected when they were infected with Salmonella. The smaller reduction in milk yield in parity 2 cows compared with the other parities was also observed in a smaller study, where milk yield from cows with high antibody levels was compared with that of herdmates with low antibody levels in endemically infected herds (T. D. Nielsen and L. R. Nielsen, unpublished data). A possible explanation for this pattern could be different management strategies (e.g., culling patterns) in case herds compared with control herds as a result of herd infection. The ratio between parity 1 and 2 observations decreased over time in case herds, whereas it remained constant in control herds. Consequently, it is possible that farmers in case herds culled a larger proportion of parity 2 cows because of poor milk production, which might explain the different pattern in this parity compared with parity 1 and $3+$.

It took 15 mo (until $\mathrm{T}_{5}$ ) for milk yield to reach preinfection levels, suggesting either that infected cows were affected for a long time or that infection spread slowly through the herd and different cattle were affected over a prolonged period. It was not possible to discern which of these occurred in our study because Salmonella status was a herd variable. Even though the BTM antibody levels generally decreased after the initial sudden increases, 19 of the 28 infected herds still had BTM antibody levels $>25 \mathrm{ODC} \%$ at $\mathrm{T}_{5}$ (data not shown). Previous studies have shown that Salmonella can be present in herds without necessarily affecting milk yield, and it is possible that herd immunity develops with repeated exposure and reinfection of the cows (Steinbach et al., 1996). Some herds had a second increase in BTM antibody level 1 to 2 yr after the initial increase, and this could indicate a reinfection of the cows in these herds that may have led to repeated periods of decreased milk yield. However, because of insufficient data, we were unable to analyze the differences in milk yield losses in the case herds with persistently 
Table 5. Multilevel analysis for main fixed effects on test-day ECM for parity 3 or higher for 28 Danish Holstein herds with large, sudden increases in bulk tank milk Salmonella antibody levels indicative of recent herd infection

\begin{tabular}{|c|c|c|c|c|}
\hline Variable & Mean & SEM & $\mathrm{LCL}^{1}$ & $\mathrm{UCL}^{1}$ \\
\hline Intercept & 39.24 & 1.97 & 35.39 & 43.10 \\
\hline $\mathrm{DIM}^{4}$ & -0.05 & 0.00 & -0.06 & -0.05 \\
\hline $\operatorname{Exp}(\mathrm{ECM})^{(-0.05 \times \mathrm{DIM})}$ & -6.28 & 0.32 & -6.90 & -5.65 \\
\hline $\operatorname{LogSCC}^{5}$ & -0.81 & 0.04 & -0.89 & -0.72 \\
\hline \multicolumn{5}{|l|}{ Year } \\
\hline 2005 & 0 & - & - & - \\
\hline 2006 & -0.06 & 1.87 & -3.72 & 3.60 \\
\hline 2007 & 0.32 & 1.88 & -3.37 & 4.01 \\
\hline 2008 & -0.69 & 1.92 & -4.46 & 3.07 \\
\hline 2009 & 1.33 & 2.03 & -2.65 & 5.30 \\
\hline \multicolumn{5}{|l|}{ Season } \\
\hline Fall & 0 & - & - & - \\
\hline Winter & -0.50 & 0.41 & -1.30 & 0.30 \\
\hline Spring & 3.01 & 0.93 & 1.18 & 4.83 \\
\hline Summer & 0.66 & 0.46 & -0.24 & 1.57 \\
\hline \multicolumn{5}{|c|}{ Standardized test-day ECM/time period ${ }^{2}$} \\
\hline$-4(-12$ to -10$)$ & 1.42 & 1.91 & -2.33 & 5.18 \\
\hline$-3(-9$ to -7$)$ & 2.12 & 1.93 & -1.66 & 5.90 \\
\hline$-2(-6$ to -4$)$ & 0.75 & 2.18 & -3.52 & 5.01 \\
\hline$-1(-3$ to -1$)$ & -1.24 & 1.95 & -5.07 & 2.59 \\
\hline $0(1$ to 3$)$ & 0 & - & - & - \\
\hline $1(4$ to 6$)$ & -0.49 & 0.83 & -2.12 & 1.14 \\
\hline $2(7$ to 9$)$ & -4.27 & 1.27 & -6.75 & -1.79 \\
\hline $3(10$ to 12$)$ & -3.62 & 0.76 & -5.12 & -2.12 \\
\hline $4(13$ to 15$)$ & -1.22 & 0.62 & -2.43 & -0.01 \\
\hline $5(16$ to 18$)$ & 1.33 & 0.64 & 0.08 & 2.57 \\
\hline \multicolumn{5}{|l|}{ Random effects } \\
\hline Herd-level variance & 7.98 & 2.92 & & \\
\hline Cow-level variance & 27.75 & 1.02 & & \\
\hline Test-day ECM level variance & 26.02 & 0.30 & & \\
\hline
\end{tabular}

high antibodies and herds where antibodies returned to lower levels within the study period.

The variance of milk yield was greater before than after the estimated infection date in case herds, and was greater in case herds than in control herds. Descriptive analyses of the data confirmed this pattern, and it is probably due to factors that were not adjusted for in the model, such as presence of other diseases, management routines, and purchase patterns. Such diseases might not affect all cows, leading to higher variance in milk yield in case herds than control herds. Unfortunately, we did not have information available about other diseases in the herds.

\section{Herd Classification}

We used an increase in BTM antibody level as sign of introduction of Salmonella to the herd. The cut-off level for a herd classified as level 2 in the Danish surveillance program is $\geq 25 \mathrm{ODC} \%$. The negative predictive value of this has been estimated to be 0.98 to 0.99 when the overall herd prevalence is 0.15 to 0.30 , indicating 1 to $2 \%$ false-negative herds (Warnick et al., 2006). We used a $<10$ ODC\% cut-off for the control herds to increase the probability that cows in the control herds had no antibodies and hence no exposure to Salmonella. Thus, we believe that the control herds were unlikely to have been misclassified. Likewise, we used a cut-off of $\geq 70$ ODC\% for the case herds to increase confidence that active infection with Salmonella existed in the herds. Furthermore, we only included case herds with antibody levels $\geq 25$ ODC $\%$ following the initial high test value, which reduced the risk of herds being false positives. The positive predictive value of the surveillance program has been estimated to be 0.68 to 0.88 depending on the underlying true prevalence of between-herd infection (Warnick et al., 2006). By using the higher cut-off point for case herds, we believe that the positive predictive value was improved, which increased our confidence that the case herds were truly infected with Salmonella.

It is impossible to know which cows in the case herds had clinical signs of salmonellosis, which were subclinically infected, and which were nondiseased or noninfected, because it was not possible to obtain animallevel data on infection status. This would have required 



Figure 1. Predicted daily milk yield mean ( $\mathrm{kg}$ of ECM) relative to that 1 to 3 mo after Salmonella infection $(\mathrm{T0})$ for case $(\mathrm{n}=28)$ and control $(\mathrm{n}=40)$ herds. $\mathrm{T}_{-4}$ is 12 to 10 mo before estimated herd infection, $\mathrm{T}_{-3}$ is 9 to 7 mo before, $\mathrm{T}_{-2}$ is 6 to 4 mo before, $\mathrm{T}_{-1}$ is 3 to 1 mo before, $\mathrm{T}_{0}$ is 1 to 3 mo after, $\mathrm{T}_{1}$ is 4 to 6 mo after, $\mathrm{T}_{2}$ is 7 to 9 mo after, $\mathrm{T}_{3}$ is 10 to 12 mo after, $\mathrm{T}_{4}$ is 13 to 15 mo after, and $\mathrm{T}_{5}$ is 16 to 18 mo after herd infection. Bars represent $95 \%$ CI of mean milk yield.

frequent repeated measurements at the animal level over a long period; even then, it would be complicated to classify the cows correctly to determine infection dates for each animal (Nielsen et al., 2004, 2007a). Therefore, the estimates of milk yield changes were estimated as averages and variations across all cows in the respective parities in the selected case herds. However, Hoorfar et al. (1995) reported that herds with outbreaks of salmonellosis caused by Salmonella Dublin within the last 6 mo all had BTM antibody levels optical density $>0.5$, a cut-off equivalent to approximately 30 to 40 ODC\% in the ELISA used in the surveillance program. In this study, we used a higher cut-off for inclusion of case herds, so it is likely that some cows had clinical signs of salmonellosis during the spread of infection. Nielsen and Ersbøll (2005) found that although not all cows need to be infected to cause a large increase in BTM antibodies, the prevalence of antibody-positive cows (ODC\% > 25) was usually above 50\% at BTM ELISA values of $70 \mathrm{ODC} \%$, and herds with such high BTM ELISA values were frequently found to be bacteriologically positive. This suggests that a large proportion of the cows in the case herds selected for our study were exposed to Salmonella bacteria, but it is likely that at all time points after the estimated time of infection, both uninfected and infected cows were present in each case herd. The infection could then continue to spread over the following 6 to 12 mo. Because the increase in BTM antibodies occurred before reduction in milk yield, it is likely that introduction of Salmonella to the herd caused the decrease in yield.

In the Danish surveillance program, antibodies toward group D antigens are measured, which in cattle is very often Salmonella Dublin. A difference might exist in how much infection with different Salmonella serotypes affects milk yield. Because Salmonella Dublin is host-adapted to cattle, it might affect yield, whereas non-host-adapted serotypes such as Salmonella Menhaden might not. The risk exists of other serotypes crossreacting with the test used in the Danish surveillance program. In Denmark, the other serotype would be primarily Salmonella Typhimurium. However, the most frequently isolated serotype from cattle is Salmonella Dublin (National Food Institute, 2009), and we therefore consider the majority of the case herds to have been infected with Salmonella Dublin.

\section{Infection Date}

Detection of Salmonella in BTM showed a seasonal trend, with most herds being infected from August through December. This is similar to the patterns observed in the national surveillance program, where an increase in herds with high BTM antibody levels occurs in the fall. Consequently, simulated infection dates for control herds were weighted by year and month of in- 
fection as in the case herds. Hence, we believe that the pattern seen after $\mathrm{T}_{0}$ was due to Salmonella.

\section{Strengths and Limitations of the Study}

Our study included 68 dairy herds and is, to our knowledge, the largest study to model associations between Salmonella and milk yield. Furthermore, it describes the yield from 12 mo before to 18 mo after estimated herd infection. The next largest study of Salmonella and milk yield followed 24 herds (Anderson et al., 1997) with Salmonella Menhaden infection. In that study, clinical signs were mainly diarrhea, which affected 0 to $40 \%$ (mean $7 \%$ ) of production groups. The 8 case herds had similar production levels to the 16 control herds.

Confounding variables other than those included in this study could lead to decreased milk yield (e.g., management). We used registry data for this study, so it was not possible to include management practices; however, including the random effect of farm accounted for unexplained between-herd variance in yield. The case herds had fewer parity $3+$ observations than the control herds but case and control herds had similar numbers of observations for parity 1 . This could be an indication of different management practices in the case and control herds. However, the ratio between parity 1 and parity $3+$ for the case herds was constant throughout the time periods, which indicates that the management practices (e.g., culling decisions) did not change for the case herds after estimated herd infection. One peculiarity in the results was the significantly reduced milk yield for parity 2 cows in $\mathrm{T}_{-2}$ in control herds (4 to 6 mo before the artificially selected infection date for the herd). This is difficult to explain but could be due to confounding variables not included in the model.

Control herds were selected randomly from all conventional Danish Holstein dairy herds with consistently low BTM antibody levels. Case herds in the period 2005 to 2009 with conventional farming practice and Danish Holstein cows were included in the study, and these herds were larger on average than the control herds. However, we observed no significant difference in herd size between case and control herds and herd size did not affect test-day ECM when included in the model, so the difference in herd size between case and control herds did not appear to affect the results. It is not known whether other breeds of cattle or organic herds would be affected in a similar way to the study herds if Salmonella were introduced into the herd, but approximately $73 \%$ of Danish dairy cows are Holsteins and $90 \%$ are on conventional farms (Knowledge Centre for Agriculture, 2009), so the results of this study are likely to be representative of the majority of Danish farms.

\section{CONCLUSIONS}

A significant decrease in milk yield occurred in Salmonella-infected herds, with mean estimated milk yield loss for a herd with 85 cows being 29,000 kg of ECM in the 18 mo following estimated time of introduction of infection to the herd. The reduction is detectable several months after the increase in bulk tank milk Salmonella antibodies, and milk yield did not return to preinfection levels for more than 1 yr following infection.

\section{ACKNOWLEDGMENTS}

Jørgen Nielsen from the Danish Cattle Federation (Aarhus, Denmark) is thanked for providing data. This study was funded by the Danish Cattle Federation and the Faculty of Life Sciences, University of Copenhagen (Denmark).

\section{REFERENCES}

Amory, J. R., Z. E. Barker, J. L. Wright, S. A. Mason, R. W. Blowey, and L. E. Green. 2008. Associations between sole ulcer, white line disease and digital dermatitis and the milk yield of 1824 dairy cows on 30 dairy cow farms in England and Wales from February 2003-November 2004. Prev. Vet. Med. 83:381-391.

Anderson, R. J., J. K. House, B. P. Smith, H. Kinde, R. L. Walker, B. J. Vande Steeg, and R. E. Breitmeyer. 2001. Epidemiologic and biological characteristics of salmonellosis in three dairy herds. J. Am. Vet. Med. Assoc. 219:310-322.

Anderson, R. J., R. L. Walker, D. W. Hird, and P. C. Blanchard. 1997. Case-control study of an outbreak of clinical disease attributable to Salmonella Menhaden infection in eight dairy herds. J. Am. Vet. Med. Assoc. 210:528-530.

Bazeley, K. 2006. An outbreak of salmonellosis in a Somerset dairy herd. UK Vet. Livest. 11:42-46.

Bennedsgaard, T. W., C. Enevoldsen, S. M. Thamsborg, and M. Vaarst. 2003. Effect of mastitis treatment and somatic cell counts on milk yield in Danish organic dairy cows. J. Dairy Sci. 86:31743183.

Breen, J. E., M. J. Green, and A. J. Bradley. 2009. Quarter and cow risk factors associated with the occurrence of clinical mastitis in dairy cows in the United Kingdom. J. Dairy Sci. 92:2551-2561.

European Food Safety Authority. 2010. The Community Summary Report on trends and sources of zoonoses, zoonotic agents and food-borne outbreaks in the European Union in 2008. EFSA J. 8:26-109.

Gay, J. M., and M. E. Hunsaker. 1993. Isolation of multiple Salmonella serovars from a dairy two years after a clinical salmonellosis outbreak. J. Am. Vet. Med. Assoc. 203:1314-1320.

Helms, M., P. Vastrup, P. Gerner-Smidt, K. Molbak, and S. Evans. 2003. Short and long term mortality associated with foodborne bacterial gastrointestinal infections: Registry based study. BMJ 326:357-361.

Hermesch, D. R., D. U. Thomson, G. H. Loneragan, D. R. Renter, and B. J. White. 2008. Effects of a commercially available vaccine against Salmonella enterica serotype Newport on milk production, 
somatic cell count, and shedding of Salmonella organisms in female dairy cattle with no clinical signs of salmonellosis. Am. J. Vet. Res. 69:1229-1234.

Hoorfar, J., P. Lind, and V. Bitsch. 1995. Evaluation of an O antigen enzyme-linked immunosorbent assay for screening of milk samples for Salmonella Dublin infection in dairy herds. Can. J. Vet. Res. 59:142-148.

House, J. K., M. M. Ontiveros, N. M. Blackmer, E. L. Dueger, J. B. Fitchhorn, G. R. McArthur, and B. P. Smith. 2001. Evaluation of an autogenous Salmonella bacterin and a modified live Salmonella serotype Choleraesuis vaccine on a commercial dairy farm. Am. J. Vet. Res. 62:1897-1902.

House, J. K., B. P. Smith, G. W. Dilling, and L. D. Roden. 1993. Enzyme-linked immunosorbent assay for serologic detection of Salmonella Dublin carriers on a large dairy. Am. J. Vet. Res. 54:1391-1399.

Huston, C. L., T. E. Wittum, and B. C. Love. 2002. Persistent fecal Salmonella shedding in five dairy herds. J. Am. Vet. Med. Assoc. 220:650-655

John, F. V. 1946. A preliminary note on Salmonella Dublin infection in adult cattle. Vet. Rec. 58:211-212.

Knowledge Centre for Agriculture. 2009. Håndbog i kvæghold (In Danish). Knowledge Centre for Agriculture, Arhus, Denmark.

McClure, L. H., S. A. McEwen, and S. W. Martin. 1989. The associations between milk production, milk composition and Salmonella in the bulk milk supplies of dairy farms in Ontario. Can. J. Vet. Res. 53:188-194.

National Food Institute. 2009. Annual Report on Zoonoses in Denmark 2008. National Food Institute, Technical University of Denmark, Copenhagen.

National Food Institute. 2010. Annual Report on Zoonoses in Denmark 2009. National Food Institute, Technical University of Denmark, Copenhagen.

Nielsen, L. R., B. d. Borne, and G. v. Schaik. 2007a. Salmonella Dublin infection in young dairy calves: Transmission parameters estimated from field data and an SIR-model. Prev. Vet. Med. 79:46-58.

Nielsen, L. R., and A. K. Ersbøll. 2005. Factors associated with variation in bulk-tank-milk Salmonella Dublin ELISA ODC\% in dairy herds. Prev. Vet. Med. 68:165-179.

Nielsen, L. R., Y. H. Schukken, Y. T. Grohn, and A. K. Ersbøll. 2004. Salmonella Dublin infection in dairy cattle: Risk factors for becoming a carrier. Prev. Vet. Med. 65:47-62.
Nielsen, L. R., L. D. Warnick, and M. Greiner. 2007b. Risk factors for changing test classification in the Danish surveillance program for Salmonella in dairy herds. J. Dairy Sci. 90:2815-2825.

Rasbash, J., C. Charlton, W. J. Browne, M. Healy, and B. Cameron. 2009. MLwiN Version 2.1. Centre for Multilevel Modelling, University of Bristol, UK.

Robertsson, J. A. 1984. Humoral antibody responses to experimental and spontaneous Salmonella infections in cattle measured by ELISA. Zentralbl. Veterinarmed. B 31:367-380.

Sanders, A. H., J. K. Shearer, and A. d. Vries. 2009. Seasonal incidence of lameness and risk factors associated with thin soles, white line disease, ulcers, and sole punctures in dairy cattle. J. Dairy Sci. 92:3165-3174.

Sjaunja, L. O., L. Baevre, L. Junkkarinen, J. Pedersen, and J. Setala. 1990. A Nordic proposal for an energy corrected milk (ECM) formula. Pages 156-157 in Perfomance Recording of Animals: State of the Art 1990. Centre for Agricultural Publishing and Documentation (PUDOC), Wageningen, the Netherlands.

Steinbach, G., H. Koch, H. Meyer, and C. Klaus. 1996. Influence of prior infection on the dynamics of bacterial counts in calves experimentally infected with Salmonella Dublin. Vet. Microbiol. 48:199-206.

Van Kessel, J. S., J. S. Karns, D. R. Wolfgang, E. Hovingh, and Y. H. Schukken. 2007. Longitudinal study of a clonal, subclinical outbreak of Salmonella enterica ssp. enterica serovar Cerro in a U.S. dairy herd. Foodborne Pathog. Dis. 4:449-461.

Vandegraaff, R., and J. Malmo. 1977. Salmonella Dublin in dairy cattle. Aust. Vet. J. 53:453-455.

Veling, J. 2004. Diagnosis and control of Salmonella Dublin infections on Dutch dairy farms. PhD Thesis. University of Utrecht, Groningen, the Netherlands.

Warnick, L. D., L. R. Nielsen, J. Nielsen, and M. Greiner. 2006. Simulation model estimates of test accuracy and predictive values for the Danish Salmonella surveillance program in dairy herds. Prev. Vet. Med. 77:284-303.

Wilmink, J. B. M. 1987. Adjustment of test-day milk, fat and protein yield for age, season and stage of lactation. Livest. Prod. Sci. $16: 335-348$

\section{APPENDIX}

Table A1. Results for interactions in multilevel analysis for fixed effects on ECM yield for parities 1 and 2 for 28 Danish Holstein herds with large, sudden increases in bulk tank milk Salmonella antibody levels indicative of recent herd infection

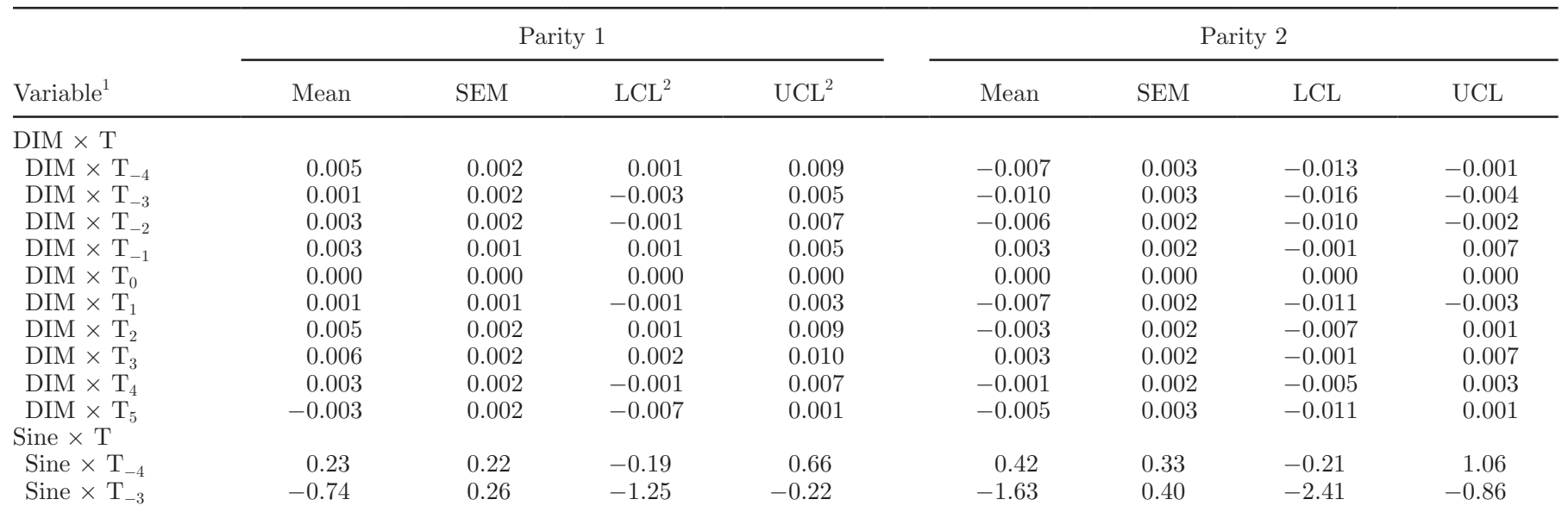


Table A1 (Continued). Results for interactions in multilevel analysis for fixed effects on ECM yield for parities 1 and 2 for 28 Danish Holstein herds with large, sudden increases in bulk tank milk Salmonella antibody levels indicative of recent herd infection

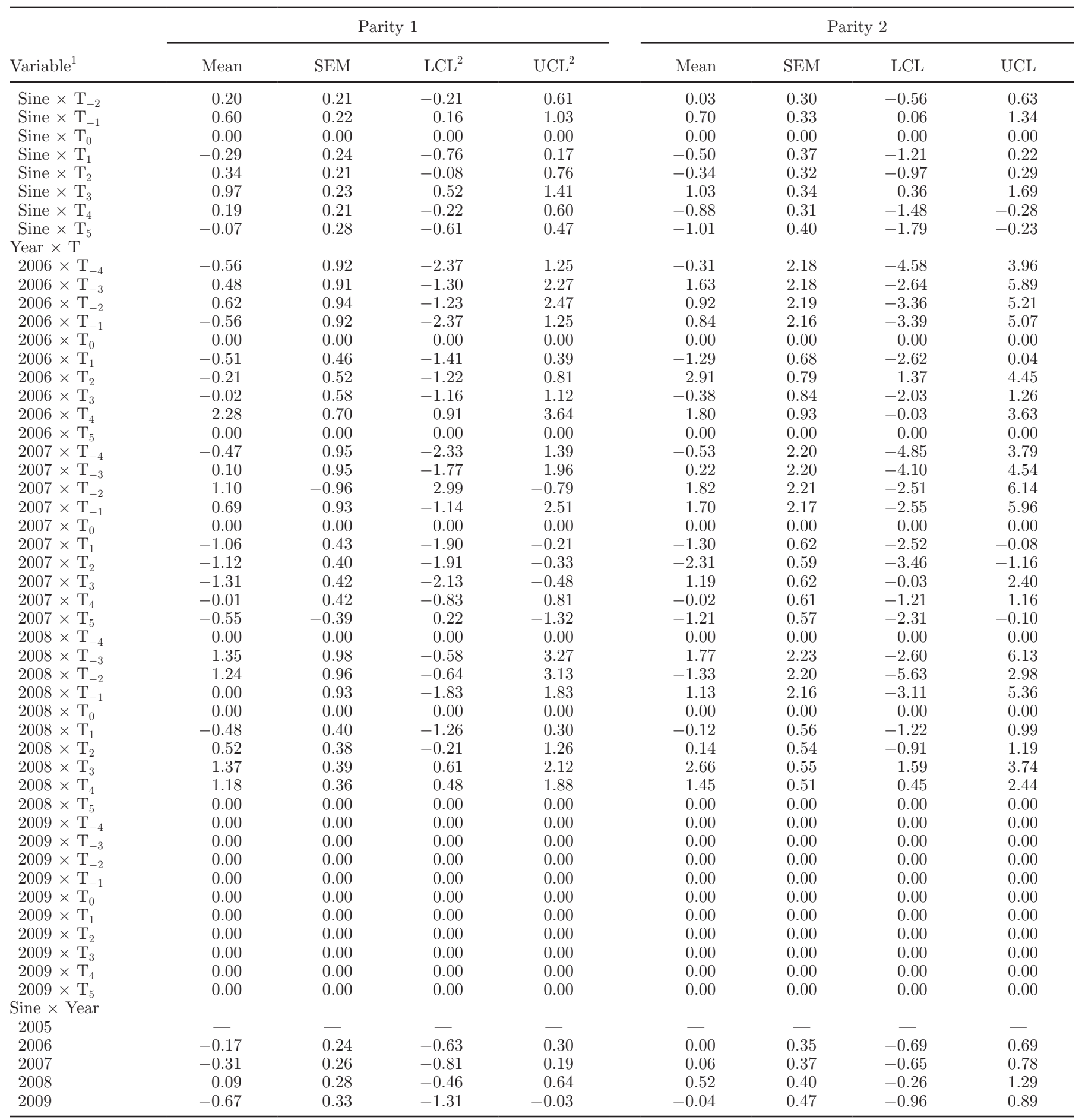

${ }^{1} \mathrm{~T}_{-4}$ is 12 to 10 mo before estimated herd infection, $\mathrm{T}_{-3}$ is 9 to 7 mo before, $\mathrm{T}_{-2}$ is 6 to 4 mo before, $\mathrm{T}_{-1}$ is 3 to $1 \mathrm{mo}$ before, $\mathrm{T}_{0}$ is 1 to 3 mo after, $\mathrm{T}_{1}$ is 4 to 6 mo after, $\mathrm{T}_{2}$ is 7 to 9 mo after, $\mathrm{T}_{3}$ is 10 to $12 \mathrm{mo}$ after, $\mathrm{T}_{4}$ is 13 to $15 \mathrm{mo}$ after, and $\mathrm{T}_{5}$ is 16 to 18 mo after herd infection.

${ }^{2} \mathrm{LCL}$ and $\mathrm{UCL}=$ lower and upper confidence limits. 
Table A2. Results for interactions in multilevel analysis for fixed effects on ECM yield for parity 3 or higher in 28 Danish Holstein herds with large, sudden increases in bulk tank milk Salmonella antibody levels indicative of recent herd infection

\begin{tabular}{|c|c|c|c|c|}
\hline \multirow[b]{2}{*}{ Variable $^{1}$} & \multicolumn{4}{|c|}{ Parity $3+$} \\
\hline & Mean & SEM & $\mathrm{LCL}^{2}$ & $\mathrm{UCL}^{2}$ \\
\hline \multicolumn{5}{|l|}{$\mathrm{DIM} \times \mathrm{T}$} \\
\hline $\mathrm{DIM} \times \mathrm{T}_{-4}$ & -0.003 & 0.002 & -0.007 & 0.001 \\
\hline $\mathrm{DIM} \times \mathrm{T}_{-3}^{-4}$ & -0.008 & 0.002 & -0.012 & -0.004 \\
\hline $\mathrm{DIM} \times \mathrm{T}_{-2}$ & -0.006 & 0.002 & -0.010 & -0.002 \\
\hline $\mathrm{DIM} \times \mathrm{T}_{-1}$ & 0.003 & 0.002 & -0.001 & 0.007 \\
\hline $\mathrm{DIM} \times \mathrm{T}_{0}$ & 0.000 & 0.000 & 0.000 & 0.000 \\
\hline $\mathrm{DIM} \times \mathrm{T}_{1}$ & -0.004 & 0.002 & -0.008 & 0.000 \\
\hline $\mathrm{DIM} \times \mathrm{T}_{2}$ & 0.000 & 0.002 & -0.004 & 0.004 \\
\hline $\mathrm{DIM} \times \mathrm{T}_{3}$ & 0.001 & 0.002 & -0.003 & 0.005 \\
\hline $\mathrm{DIM} \times \mathrm{T}_{4}$ & -0.003 & 0.002 & -0.007 & 0.001 \\
\hline $\mathrm{DIM} \times \mathrm{T}_{5}$ & -0.008 & 0.002 & -0.012 & -0.004 \\
\hline \multicolumn{5}{|l|}{ Year $\times \mathrm{T}$} \\
\hline $2006 \times \mathrm{T}_{-4}$ & 1.45 & 1.92 & -2.30 & 5.21 \\
\hline $2006 \times \mathrm{T}_{-3}$ & 0.74 & 1.91 & -3.00 & 4.47 \\
\hline $2006 \times \mathrm{T}_{-2}$ & 2.00 & 1.98 & -1.88 & 5.89 \\
\hline $2006 \times \mathrm{T}_{-1}$ & 0.99 & 1.93 & -2.80 & 4.77 \\
\hline $2006 \times \mathrm{T}_{0}$ & 0.00 & 0.00 & 0.00 & 0.00 \\
\hline $2006 \times \mathrm{T}_{1}$ & 2.12 & 0.68 & 0.78 & 3.46 \\
\hline $2006 \times \mathrm{T}_{2}$ & 1.81 & 0.94 & -0.03 & 3.65 \\
\hline $2006 \times \mathrm{T}_{3}$ & 3.79 & 0.94 & 1.95 & 5.63 \\
\hline $2006 \times \mathrm{T}_{4}$ & 2.61 & 0.97 & 0.71 & 4.50 \\
\hline $2006 \times \mathrm{T}_{5}$ & 0.00 & 0.00 & 0.00 & 0.00 \\
\hline $2007 \times \mathrm{T}_{-4}$ & 0.36 & 1.93 & -3.42 & 4.13 \\
\hline $2007 \times \mathrm{T}_{-3}$ & 0.62 & 1.93 & -3.17 & 4.40 \\
\hline $2007 \times \mathrm{T}_{-2}$ & 4.07 & 2.01 & 0.13 & 8.01 \\
\hline $2007 \times \mathrm{T}_{-1}$ & 1.34 & 1.96 & -2.51 & 5.18 \\
\hline $2007 \times \mathrm{T}_{0}$ & 0.00 & 0.00 & 0.00 & 0.00 \\
\hline $2007 \times \mathrm{T}_{1}$ & 0.65 & 0.67 & -0.65 & 1.95 \\
\hline $2007 \times \mathrm{T}_{2}$ & 0.66 & 0.65 & -0.61 & 1.93 \\
\hline $2007 \times \mathrm{T}_{3}$ & 0.21 & 0.64 & -1.05 & 1.47 \\
\hline $2007 \times \mathrm{T}_{4}$ & 0.14 & 0.63 & -1.10 & 1.38 \\
\hline $2007 \times \mathrm{T}_{5}$ & -1.02 & 0.65 & -2.29 & 0.24 \\
\hline $2008 \times \mathrm{T}_{-4}$ & 0.00 & 0.00 & 0.00 & 0.00 \\
\hline $2008 \times \mathrm{T}_{-3}$ & 1.17 & 1.94 & -2.63 & 4.96 \\
\hline $2008 \times \mathrm{T}_{-2}$ & 2.38 & 2.01 & -1.56 & 6.33 \\
\hline $2008 \times \mathrm{T}_{-1}$ & 0.24 & 1.96 & -3.61 & 4.08 \\
\hline $2008 \times \mathrm{T}_{0}$ & 0.00 & 0.00 & 0.00 & 0.00 \\
\hline $2008 \times \mathrm{T}_{1}$ & 1.90 & 0.57 & 0.79 & 3.01 \\
\hline $2008 \times \mathrm{T}_{2}$ & 2.59 & 0.60 & 1.40 & 3.77 \\
\hline $2008 \times \mathrm{T}_{3}$ & 3.85 & 0.59 & 2.70 & 5.00 \\
\hline $2008 \times \mathrm{T}_{4}$ & 1.30 & 0.52 & 0.28 & 2.32 \\
\hline $2008 \times \mathrm{T}_{5}$ & 0.00 & 0.00 & 0.00 & 0.00 \\
\hline $2009 \times \mathrm{T}_{-4}$ & 0.00 & 0.00 & 0.00 & 0.00 \\
\hline $2009 \times \mathrm{T}_{-3}$ & 0.00 & 0.00 & 0.00 & 0.00 \\
\hline $2009 \times \mathrm{T}_{-2}$ & 0.00 & 0.00 & 0.00 & 0.00 \\
\hline $2009 \times \mathrm{T}_{-1}$ & 0.00 & 0.00 & 0.00 & 0.00 \\
\hline $2009 \times \mathrm{T}_{0}$ & 0.00 & 0.00 & 0.00 & 0.00 \\
\hline $2009 \times \mathrm{T}_{1}$ & 0.00 & 0.00 & 0.00 & 0.00 \\
\hline $2009 \times \mathrm{T}_{2}$ & 0.00 & 0.00 & 0.00 & 0.00 \\
\hline $2009 \times \mathrm{T}_{3}$ & 0.00 & 0.00 & 0.00 & 0.00 \\
\hline $2009 \times \mathrm{T}_{4}$ & 0.00 & 0.00 & 0.00 & 0.00 \\
\hline $2009 \times \mathrm{T}_{5}$ & 0.00 & 0.00 & 0.00 & 0.00 \\
\hline \multicolumn{5}{|l|}{ Season $\times \mathrm{T}$} \\
\hline Spring $\times \mathrm{T}_{-4}$ & -2.70 & 1.27 & -5.19 & -0.21 \\
\hline Spring $\times \mathrm{T}_{-3}$ & -2.27 & 1.03 & -4.29 & -0.26 \\
\hline Spring $\times \mathrm{T}_{-2}$ & -3.93 & 1.66 & -7.19 & -0.67 \\
\hline Spring $\times \mathrm{T}_{-1}$ & -0.60 & 1.19 & -2.92 & 1.73 \\
\hline Spring $\times \mathrm{T}_{0}$ & 0.00 & 0.00 & 0.00 & 0.00 \\
\hline Spring $\times \mathrm{T}_{1}$ & -3.31 & 1.08 & -5.43 & -1.20 \\
\hline Spring $\times \mathrm{T}_{2}$ & 0.10 & 1.53 & -2.90 & 3.10 \\
\hline Spring $\times \mathrm{T}_{3}$ & -0.28 & 1.11 & -2.45 & 1.90 \\
\hline Spring $\times \mathrm{T}_{4}$ & -2.14 & 1.20 & -4.48 & 0.21 \\
\hline
\end{tabular}


Table A2 (Continued). Results for interactions in multilevel analysis for fixed effects on ECM yield for parity 3 or higher in 28 Danish Holstein herds with large, sudden increases in bulk tank milk Salmonella antibody levels indicative of recent herd infection

\begin{tabular}{lrrrr}
\hline & \multicolumn{3}{c}{ Parity $3+$} \\
\cline { 2 - 5 } Variable $^{1}$ & Mean & SEM & LCL $^{2}$ & UCL $^{2}$ \\
\hline Spring $\times \mathrm{T}_{5}$ & -1.48 & 1.02 & -3.49 & 0.52 \\
Summer $\times \mathrm{T}_{-4}$ & -1.23 & 0.60 & -2.40 & -0.05 \\
Summer $\times \mathrm{T}_{-3}$ & -0.68 & 1.13 & -2.89 & 1.54 \\
Summer $\times \mathrm{T}_{-2}$ & 0.07 & 1.23 & -2.34 & 2.48 \\
Summer $\times \mathrm{T}_{-1}$ & 0.33 & 0.64 & -0.92 & 1.59 \\
Summer $\times \mathrm{T}_{0}$ & 0.00 & 0.00 & -3.00 & 0.00 \\
Summer $\times \mathrm{T}_{1}$ & -0.88 & 1.22 & -0.68 & 3.50 \\
Summer $\times \mathrm{T}_{2}$ & 1.41 & 1.07 & 0.08 & 2.59 \\
Summer $\times \mathrm{T}_{3}$ & 1.34 & 0.64 & -0.35 & 2.00 \\
Summer $\times \mathrm{T}_{4}$ & 0.83 & 0.60 & -1.90 & 2.78 \\
Summer $\times \mathrm{T}_{5}$ & 0.44 & 1.19 & -0.75 & 1.41 \\
Winter $\times \mathrm{T}_{-4}$ & 0.33 & 0.55 & -2.89 & 2.56 \\
Winter $\times \mathrm{T}_{-3}$ & -0.68 & 1.13 & 0.04 & 4.05 \\
Winter $\times \mathrm{T}_{-2}$ & -0.15 & 1.38 & 0.00 & 0.00 \\
Winter $\times \mathrm{T}_{-1}$ & 2.04 & 1.02 & -1.03 & 1.58 \\
Winter $\times \mathrm{T}_{0}$ & 0.00 & 0.00 & 1.13 & 5.91 \\
Winter $\times \mathrm{T}_{1}$ & 0.27 & 0.67 & -1.66 & 3.39 \\
Winter $\times \mathrm{T}_{2}$ & 3.52 & 1.22 & -0.52 & 1.50 \\
Winter $\times \mathrm{T}_{3}$ & 0.86 & 1.29 & -0.50 & 1.63 \\
Winter $\times \mathrm{T}_{4}$ & 0.49 & 0.52 & 0.54 & \\
Winter $\times \mathrm{T}_{5}$ & 0.57 & 15 & \\
\hline
\end{tabular}

${ }^{1} \mathrm{~T}_{-4}$ is 12 to 10 mo before estimated herd infection, $\mathrm{T}_{-3}$ is 9 to 7 mo before, $\mathrm{T}_{-2}$ is 6 to 4 mo before, $\mathrm{T}_{-1}$ is 3 to 1 mo before, $\mathrm{T}_{0}$ is 1 to 3 mo after, $\mathrm{T}_{1}$ is 4 to 6 mo after, $\mathrm{T}_{2}$ is 7 to 9 mo after, $\mathrm{T}_{3}$ is 10 to 12 mo after, $\mathrm{T}_{4}$ is 13 to 15 mo after, and $\mathrm{T}_{5}$ is 16 to 18 mo after herd infection.

${ }^{2} \mathrm{LCL}$ and $\mathrm{UCL}=$ lower and upper confidence limits. 